\title{
Genetic Divergence in Urena lobata Accessions to Quantitative Traits
}

\author{
Lucinete Miranda Gomes ${ }^{1}$, Albejamere Pereira de Castro ${ }^{1}$, Therezinha de Jesus Pinto Fraxe ${ }^{1}$, \\ Pedro de Queiroz Costa Neto², Angela Maria da Silva Mendes², Mágno Sávio Ferreira Valente², \\ Carla Coelho Ferreira ${ }^{1} \&$ Maria Luiza Andrade Pereira ${ }^{2}$ \\ ${ }^{1}$ Postgraduate Program in Tropical Agronomy, Federal University of Amazonas, Manaus, Amazonas, Brazil \\ ${ }^{2}$ Federal University of Amazonas, Manaus, Amazonas, Brazil \\ Correspondence: Lucinete Miranda Gomes, Nucleus of Socioeconomics (NUSEC), Federal University of \\ Amazonas, Av. General Rodrigo Octávio Jordão Ramos, 6200-Coroado I, Manaus, Amazonas, Brazil. Tel: \\ 55-92-99612-0193. E-mail: lgomes2070@yahoo.com.br
}

Received: November 30, 2018

Accepted: May 11, 2019 Online Published: July 31, 2019

doi:10.5539/jas.v11n11p 81

URL: https://doi.org/10.5539/jas.v11n11p81

\begin{abstract}
In this study, 14 quantitative traits were evaluated, divided into five distinct categories, related to the plants, leaves, flowers, fruits and seeds of seven Mallow accessions belonging to the NUSEC/UFAM germplasm collection. With the characteristics measured, the genetic variability of the accessions was evaluated, aiming at the genetic improvement of the culture. Through the analysis of variance, it was possible to assemble and propose the 14 agronomic descriptors, being that with the application of the clustering method (UPGMA), which generated a dendrogram of dissimilarity, it was possible to divide the seven genotypes into two distinct phenotypic groups, and their subgroups. The study showed that there is a great divergence between the accesses and the recommendation for the crossover is between the accesses ANÃ/MAC, ANÃ/MAQ and PIN/BER. The high heritability observed for the characters analyzed suggests the phenotypic value as a reliable measure for selection of the genotypes studied.
\end{abstract}

Keywords: Amazonia, agronomic characteristics, mallow

\section{Introduction}

The mallow (Urena lobata L.), which is a textile plant of great economic importance in the Amazon region, presents similar fibers to the jute plant (Corchorus capsularis L.). The species has been extensively cultivated in the region since the 1970s by riverine farmers in a family farming system (Noda, 2010).

Despite the great economic and social importance that the culture represents for the region, no conclusive study were reported in the literature on the genetic diversity of this species; these informations are extremely important for the implementation of programs for the conservation and pre-improvement of this crop, mainly related to the production of seeds in the State of Amazonas. It is known that one of the main bottlenecks in the production of fiber is the seed, since all the production of this input comes from the State of Pará, and does not supply the needs of the mallow farmers in Amazonas (Bentes et al., 2017).

Genetic diversity is the multiplicity of allelic frequencies present in a group of individuals, which, together with the environment, provides the nature of the phenotype and is a fundamental basis in breeding programs. Exploring the diversity of cultivated species of economic importance is a key task in all agricultural research programs (Cardona, 2010).

In this context, germplasm banks are of fundamental importance, particularly as regards the genetic variability necessary to subsidize plant breeding in obtaining superior genotypes with distinct genetic constitutions (Quintal et al., 2012). However, these accesses kept in germplasm banks should be characterized and evaluated in order to know the genetic material before introducing them into a breeding program, avoiding the use of redundant genomes, commonly known as duplicates (Franco et al., 2005; Gepts, 2006; Sudré et al., 2010).

Studies to estimate genetic diversity in germplasm banks and collections have become common in several Amazonian cultures, such as manioc (Barreto \& Resendes, 2010), cupuaçu tree (Alves et al., 2013) and guarana tree (Fajardo, 2016) between others. In order to estimate and quantify genetic variability, biometric methods are used to quantify or estimate heterosis, which are analyzed by multivariate statistics, and Mahalanobis distance is 
one of the dissimilarity measures most used to quantify the divergence between accesses (Carneiro and Regazzi, 2014).

In view of the above, it was necessary to characterize mallow accesses, originating from the municipalities of Anamã, Anori, Beruri, Caapiranga, Manacapuru, Manaquiri and Parintins, through a collection of ex situ germplasm in the solid ground area, agronomic descriptors for species. The information generated in this study made it possible to select the parents who will enable the formation of segregating populations for the selection of genotypes favorable to obtaining new cultivars, which can be used by the local producers in the production of seeds, enabling a sustainable agriculture in the region.

\section{Method}

The experiment was developed at the Experimental Farm of the Federal University of Amazonas, located at Km 38 of Highway BR-174-AM. We evaluated seven accessions of mallow collected in the municipalities (Anamã, Anori, Beruri, Caapiranga, Manacapuru, Manaquiri and Parintins) of greater relevance, as regards the production of mallow fiber in State of Amazonas (AM) (Table 1). The collection belongs to the Nucleus of Socioeconomics-NUSEC/UFAM-Brazil.

Table 1. Origin and location of the malve accessions collected in State of Amazonas (AM)

\begin{tabular}{|c|c|c|c|}
\hline \multirow{2}{*}{ Accessions } & \multicolumn{2}{|c|}{ Geographic Coordinates } & \multirow{2}{*}{ Origin } \\
\hline & Latitude & Longitude & \\
\hline ANÃ & $03^{\circ} 03^{\prime} 37^{\prime \prime} \mathrm{S}$ & $61^{\circ} 26^{\prime} 28^{\prime \prime} \mathrm{W}$ & Anamã-AM \\
\hline ANR & $03^{\circ} 36^{\prime} 58^{\prime \prime} \mathrm{S}$ & $61^{\circ} 40^{\prime} 32^{\prime \prime} \mathrm{W}$ & Anori-AM \\
\hline BER & $03^{\circ} 53^{\prime} 54^{\prime \prime} \mathrm{S}$ & $61^{\circ} 22^{\prime} 25^{\prime \prime} \mathrm{W}$ & Beruri-AM \\
\hline CAA & $03^{\circ} 19^{\prime} 42^{\prime \prime} \mathrm{S}$ & $61^{\circ} 12^{\prime} 34^{\prime \prime} \mathrm{W}$ & Caapiranga-AM \\
\hline MAC & $03^{\circ} 07^{\prime} 47^{\prime \prime} \mathrm{S}$ & $60^{\circ} 36^{\prime} 55^{\prime \prime} \mathrm{W}$ & Manacapuru-AM \\
\hline MAQ & $03^{\circ} 25^{\prime} 97^{\prime \prime} \mathrm{S}$ & $60^{\circ} 27^{\prime} 58^{\prime \prime} \mathrm{W}$ & Manaquiri-AM \\
\hline PIN & $02^{\circ} 65^{\prime} 32^{\prime \prime} \mathrm{S}$ & $56^{\circ} 74^{\prime} 95^{\prime \prime} \mathrm{W}$ & Parintins-AM \\
\hline
\end{tabular}

To obtain the seedlings, sowing was carried out in polyethylene bags in the dimensions of $15 \times 16 \mathrm{~cm}$. All treatments germinated on the third day after planting. The seedlings were monitored in the nursery of the Olericulture Sector of Experimental Farm, with daily irrigations (twice a day), and submitted to the acclimation process for a period of eight days before transplantation to the definitive site.

Field planting was carried out at 45 days after emergence of the seedlings in spacing of five meters between rows and three meters between plants. The treatments were placed in rows, with two plants per pit, with thinning occurring after establishment of the plants in the field, leaving only one plant per pit. After the transplant, was managed the management with weeds, using manual brushcutters for the control of invasive plants.

The trial was conducted on a farmland that had been fallow for over a year, classified as Yellow Latosol. No correction or soil fertilization was performed. The experimental design was in randomized blocks, with seven treatments (accessions) and four replications containing eight plants per plot.

For the agronomic characterization, 140 plants were selected in the experimental area, considering five plants per plot. The observations and data collection were carried out weekly until the production and collection of the seeds.

The characterization of the accessions was made using the descriptors of the cotton plant (Gassypium L.), a species of the same botanical family and with a characteristic similar to the mallow plant. These descriptors were defined by the MAPA (Ministry of Agriculture, Livestock and Supply), according to UPOV (International Union for the Protection of New Plant Varieties), being the minimum required for characterization of the cotton, being adapted to the mallow plant according to with the characteristics of the species.

The evaluated characteristics were height of the plant $(\mathrm{PH})$, measure taken from the base to the apex of the main stem; diameter of the stem (SD), performed at $5 \mathrm{~cm}$ above the ground; canopy diameter (CL), performed between the rows. Regarding the leaf: length of the limbus (LLE), measure taken from the base to the apex of the leaf blade; width of the limbus (WL), held in the widest part of the leaf blade; length of the petiole (LP1), from the apex to the base of the leaf. Flower: length of the petal (LP2), from the base to the apex of the petal; width of the petal (WP), on the broadest part of the petal; length of the bracts (LB), measured from the base to the apex of 
the bract; width of the bract (WB), held in the widest part of the bract. Fruit: fruit diameter (FD); length of the peduncle (LPE), from the apex to the base of the fruit. Seed: length of the seed (LS), from the base to the apex of the seed; width of the seed (WS) at the widest part of the seed.

\subsection{Statistical Analysis}

The means were analyzed by the Scott and Knott criterion (Scott \& Knott, 1974) at 1\% and 5\% probability using the Genes Software (Cruz, 2013). In order to visualize the genetic differentiation between accessions, a dendrogram was created by UPGMA (Unweighted Pair Group Method using Arithmetical Averages) with the aid of the R-Development Core Team (2018). The analysis of divergence between the treatments was obtained through the genetic distance of Mahalanobis.

\section{Results and Discussion}

\subsection{Genetic Variability of Accessions}

The analysis of variance revealed significant differences ( $\leq 0.01$ and $\mathrm{p} \leq 0.05)$ among the mallow accessions studied for the agronomic characteristics (Table 2), indicating the presence of genetic variability among the accessions tested. The exception was the characteristic crown length (CL), which did not present significant differences between the genotypes.

Table 2. Summary of variance for the characters, PH: plant height (m), SD: stem diameter (cm), CL: crown length $(\mathrm{m})$, LLE: leaf length $(\mathrm{cm})$, WL: leaf width $(\mathrm{cm}), \mathrm{LP} 1$ : length of the petiole $(\mathrm{cm}), \mathrm{LP} 2$ : length of the petal $(\mathrm{cm})$, WP: width of the petal $(\mathrm{cm})$, LB: length of the bracts $(\mathrm{mm})$. WB: width of the bract $(\mathrm{mm})$, FD: fruit diameter $(\mathrm{mm})$, LPE: length of the peduncle $(\mathrm{mm})$, LS: length of the seed $(\mathrm{mm})$, WS: width of the seed $(\mathrm{mm})$ of mallow accessions

\begin{tabular}{|c|c|c|c|c|c|c|c|c|}
\hline \multirow{2}{*}{$\mathrm{FV}$} & \multirow{2}{*}{ GL } & \multirow{2}{*}{$\mathrm{PH}$} & \multicolumn{3}{|c|}{ Agronomic characters } & \multirow{2}{*}{$\mathrm{WL}$} & \multirow{2}{*}{ LP1 } & \multirow{2}{*}{ LP2 } \\
\hline & & & SD & $\mathrm{CL}$ & LLE & & & \\
\hline Accessions & 6 & $0.6542 * *$ & $1.5124 * *$ & $0.0567^{\mathrm{ns}}$ & $5.4524 * *$ & $13.1104 * *$ & $17.4022 * *$ & $0.0252 * *$ \\
\hline Residue & 18 & 0.0710 & 0.2063 & 0.2324 & 0.5243 & 0.7986 & 21.807 & 0.0011 \\
\hline Means & & 2.48 & 7.50 & 3.82 & 9.23 & 8.71 & 7.89 & 1.65 \\
\hline $\mathrm{CV} \%$ & & 10.74 & 6.06 & 12.60 & 7.84 & 10.26 & 18.73 & 2.00 \\
\hline \multirow{2}{*}{$\mathrm{FV}$} & \multirow{2}{*}{ GL } & \multirow{2}{*}{ WP } & \multicolumn{3}{|c|}{ Agronomic characters } & I PF & I S & WS \\
\hline & & & LB & WB & FD & $\mathrm{LIL}$ & Lis & $\mathrm{WS}$ \\
\hline Accessions & 6 & $0.0364 * *$ & $0.7048 * *$ & $0.3288 * *$ & $0.1083 * *$ & $1.5254 * *$ & $0.4058 * *$ & $0.3674 *$ \\
\hline Residue & 18 & 0.0005 & 0.0695 & 0.0078 & 0.0087 & 0.1279 & 0.0118 & 0.0921 \\
\hline Means & & 0.74 & 6.90 & 1.63 & 7.63 & 4.10 & 3.88 & 2.54 \\
\hline $\mathrm{CV} \%$ & & 2.91 & 3.82 & 5.41 & 1.23 & 8.71 & 2.80 & 11.96 \\
\hline
\end{tabular}

The coefficient of variation for all the characteristics was below $20 \%$, indicating that there was little environmental influence and a more effective experimental precision on the expression of these characters. Table 3 shows the mean of the characters, compared by the Scott-Knott test $(\mathrm{p} \leq 0.05)$. This analysis allowed the formation of classes according to the characters analyzed. 
Table 3. Estimated means of PH: plant height (m), SD: stem diameter (cm), CL: crown length (m), LLE: leaf length $(\mathrm{cm})$, WL: leaf width $(\mathrm{cm})$, LP1: length of the petiole $(\mathrm{cm})$, LP2: length of the petal $(\mathrm{cm})$, WP: width of the petal $(\mathrm{cm})$, LB: length of the bracts $(\mathrm{mm})$. WB: width of the bract $(\mathrm{mm})$, FD: fruit diameter $(\mathrm{mm})$, LPE: length of the peduncle $(\mathrm{mm})$, LS: length of the seed $(\mathrm{mm})$, WS: width of the seed $(\mathrm{mm})$ of seven mallow accessions

\begin{tabular}{llllllll}
\hline \multicolumn{6}{l}{ Characteristics analyzed } & \multicolumn{5}{l}{} \\
\hline Acesses & PH & SD & CL & LLE & WL & LP1 & LP2 \\
\hline ANA & $1.90 \mathrm{c}$ & $7.04 \mathrm{~b}$ & $3.70 \mathrm{a}$ & $7.63 \mathrm{c}$ & $6.98 \mathrm{~d}$ & $4.66 \mathrm{~b}$ & $1.59 \mathrm{c}$ \\
ANR & $2.27 \mathrm{c}$ & $7.09 \mathrm{~b}$ & $3.92 \mathrm{a}$ & $9.69 \mathrm{~b}$ & $8.48 \mathrm{c}$ & $6.97 \mathrm{~b}$ & $1.65 \mathrm{~b}$ \\
BER & $2.49 \mathrm{~b}$ & $6.84 \mathrm{~b}$ & $4.02 \mathrm{a}$ & $9.32 \mathrm{~b}$ & $8.73 \mathrm{c}$ & $8.63 \mathrm{a}$ & $1.72 \mathrm{a}$ \\
CAA & $2.70 \mathrm{~b}$ & $7.51 \mathrm{~b}$ & $3.83 \mathrm{a}$ & $8.04 \mathrm{c}$ & $7.09 \mathrm{~d}$ & $6.26 \mathrm{~b}$ & $1.72 \mathrm{a}$ \\
MAC & $3.15 \mathrm{a}$ & $8.16 \mathrm{a}$ & $3.76 \mathrm{a}$ & $10.03 \mathrm{~b}$ & $9.92 \mathrm{~b}$ & $10.45 \mathrm{a}$ & $1.59 \mathrm{c}$ \\
MAQ & $2.21 \mathrm{c}$ & $7.35 \mathrm{~b}$ & $3.85 \mathrm{a}$ & $8.89 \mathrm{c}$ & $7.67 \mathrm{~d}$ & $8.10 \mathrm{a}$ & $1.75 \mathrm{a}$ \\
PIN & $2.66 \mathrm{~b}$ & $8.50 \mathrm{a}$ & $3.70 \mathrm{a}$ & $11.03 \mathrm{a}$ & $12.09 \mathrm{a}$ & $10.14 \mathrm{a}$ & $1.55 \mathrm{c}$ \\
\hline Characteristics analyzed & & & & & & \\
\hline Accessions & WP & LB & WB & FD & LPE & LS & WS \\
\hline ANÃ & $0.64 \mathrm{e}$ & $7.33 \mathrm{a}$ & $1.43 \mathrm{c}$ & $7.53 \mathrm{c}$ & $4.75 \mathrm{a}$ & $3.73 \mathrm{~b}$ & $2.31 \mathrm{~b}$ \\
ANR & $0.90 \mathrm{a}$ & $7.08 \mathrm{a}$ & $1.78 \mathrm{~b}$ & $7.45 \mathrm{c}$ & $3.49 \mathrm{c}$ & $3.68 \mathrm{~b}$ & $2.38 \mathrm{~b}$ \\
BER & $0.77 \mathrm{c}$ & $6.97 \mathrm{a}$ & $1.48 \mathrm{c}$ & $7.44 \mathrm{c}$ & $4.30 \mathrm{~b}$ & $3.59 \mathrm{~b}$ & $2.20 \mathrm{~b}$ \\
CAA & $0.70 \mathrm{~d}$ & $6.12 \mathrm{c}$ & $2.05 \mathrm{a}$ & $7.65 \mathrm{~b}$ & $3.25 \mathrm{c}$ & $3.70 \mathrm{~b}$ & $2.39 \mathrm{~b}$ \\
MAC & $0.73 \mathrm{~d}$ & $6.98 \mathrm{a}$ & $1.39 \mathrm{c}$ & $7.70 \mathrm{~b}$ & $4.92 \mathrm{a}$ & $4.40 \mathrm{a}$ & $2.85 \mathrm{a}$ \\
MAQ & $0.83 \mathrm{~b}$ & $6.57 \mathrm{~b}$ & $1.93 \mathrm{a}$ & $7.74 \mathrm{~b}$ & $4.18 \mathrm{~b}$ & $3.78 \mathrm{~b}$ & $3.02 \mathrm{a}$ \\
PIN & $0.65 \mathrm{e}$ & $7.23 \mathrm{a}$ & $1.35 \mathrm{c}$ & $7.89 \mathrm{a}$ & $3.85 \mathrm{c}$ & $4.27 \mathrm{a}$ & $2.63 \mathrm{a}$
\end{tabular}

Note. Means followed by the same letter, in each column, belong to the same group according to the Scott and Knott grouping criterion, at $5 \%$ probability.

The characterization for the descriptor plant height $(\mathrm{PH})$ was the most diverse, presenting values between $1.90 \mathrm{~m}$ (ANÃ) and $3.15 \mathrm{~m}$ (MAC), forming three classes (Table 3). Intermediate values were observed in the MAQ $(2.21 \mathrm{~m})$, ANR $(2.27 \mathrm{~m})$, BER $(2.49 \mathrm{~m})$, PIN $(2.66 \mathrm{~m})$ and CAA $(2.70 \mathrm{~m})$ approaches. It was possible to classify plants as tall, medium and low.

Bentes, Pereira, Mendes, Castro, and Cunha (2017) analyzed the spacing to produce mallow seeds, with material from the municipality of Capitão Poço, Pará, Brazil. They observed that, among the three treatments analyzed, the plants had a mean height of $2.27 \mathrm{~m}(\mathrm{~T} 1: 1 \mathrm{~m} \times 1 \mathrm{~m}), 2.22 \mathrm{~m}(\mathrm{~T} 2: 1.5 \mathrm{~m} \times 0.5 \mathrm{~m})$ and $2.19 \mathrm{~m}(\mathrm{~T} 3: 1 \mathrm{~m} \times 0.5$ $\mathrm{m}$ ), not being significant. This result is similar to those found in ANR and MAQ, however, the other accesses analyzed presented different values, highlighting the existing variability for this characteristic.

Plant height can be a very important feature depending on the selection point of view. The mallow is a shrub that reaches up to four meters high (Joly, 2002). According to Bentes et al. (2017), because it results in higher productivity, the indicated spacing for mallow seed production is $1.5 \times 0.5 \mathrm{~m}$, in which the average height of the plants was $2.22 \mathrm{~m}$. The accessions of this present study presented phenotypes of short stature, similar to those observed by Bentes et al. (2017). Plant height is one of the characteristics well worked in the improvement of species of agronomic interest, since; the selection of genotypes with smaller size facilitates both the cultural treatments, as well as the harvesting operation.

The stem diameter characteristic (SD) presented little variation and averages of $6.84 \mathrm{~cm}$ (BER) at $8.50 \mathrm{~cm}$ (PIN), forming only two classes (Table 3). Intermediate values were observed in ANÃ $(7.04 \mathrm{~cm})$, ANR $(7.09 \mathrm{~cm})$, CAA $(7.51 \mathrm{~cm})$, MAQ $(7.35 \mathrm{~cm})$ and MAC $(8.16 \mathrm{~cm})$ accessions. With the data obtained through the evaluation, a classification was proposed in larger diameter and smaller diameter. The values observed in the accessions were well above the $3.05 \mathrm{~cm}$ diameter value found by Bentes et al. (2017) in plants spaced $1 \mathrm{~m} \times 1 \mathrm{~m}$. This behavior can be explained by the lower plant density in the present study.

The methodology adopted in this study contributed to the greater development of SD in all the accessions evaluated, since this characteristic is directly related to the spacing between plants, the larger the spacing the greater its development. The strategy adopted, facilitated the management of the plants in the progress of the evaluations. 
For the characteristic crown length (CL), the analysis of variance showed no genetic variability between the accessions (Table 2). Laviola, Bhering, Mendonça, Rosada, and Albrecht (2011), characterizing accessions of jatropha, perennial species such as mallow, verified little variation for this character, discarding and recommending new assessments, once, genotypes were in the initial evaluation phase. Studies of the contribution of characters to diversity are important to select characteristics that discriminate the accessions and also to discard others, which contribute little to the discrimination of genotypes (Cruz et al., 2014). Based on the results, the CL variable was discarded and future evaluations were carried out to better discriminate this characteristic.

In the characteristics of petiole length (LP1), leaf length (LLE) and leaf width (WL), there was a significant difference between the accessions. The WL characteristic presented a greater variation between the PIN (11.03 $\mathrm{cm})$ and ANÃ $(7.63 \mathrm{~cm})$ accessions, forming four distinct classes. The evaluation of this characteristic allowed classification in narrow, medium and wide leaves. The variation for the LLE characteristic occurred in the PIN $(12.09 \mathrm{~cm})$ and ANÃ $(6.98 \mathrm{~cm})$ accessions, forming three classes, characterized as long, medium and short leaves. The variation for the evaluated characteristics occurred in the same PIN and ANÃ accessions, where the highest and the lowest values were observed, respectively. For characterization of the leaf, the characteristic that presented the smallest variation was LP1, formed only two classes. The variation occurred in MAC $(10.45 \mathrm{~cm})$ and ANÃ $(4.66 \mathrm{~cm})$. Although this trait presented only two classes, a new arrangement was made, including the intermediate classification to facilitate the application of the descriptor in the field. Through the new provision, the LP1 was classified in short, medium and long.

The LP1 is a feature closely related to LLE and WL, being evident during the evaluations, since the accessions with smaller and larger values in length and leaf width, presented the same characteristics for petiole lengths. In general, the characteristics related to the aerial part of the plant, revealed high genetic variability among the studied accessions. LP1, even with little variation, has been shown to be a good distinguishing feature of field genotypes. In the MAC and PIN accessions, plants with good characteristics in leaf area and good aeration were observed, provided by the stretching of the petioles. This characteristic was evaluated by Álves (2014) in sweet potato germplasm and Albuquerque et al. (2009), in germplasm of cassava cultivated in the State of Roraima, being reported by the authors as one of the characteristics of easy evaluation in the field.

Regarding the flower characterization, the variation for the LP2 characteristic was observed in the MAQ (1.75 $\mathrm{cm})$, BER and CAA accessions $(1.72 \mathrm{~cm})$; and PIN $(1.55 \mathrm{~cm})$, ANÃ and MAC $(1.59 \mathrm{~cm})$; and the intermediates in the access ANR $(1.65 \mathrm{~cm})$, forming three classes. Through the observation of the data, it was proposed the classification for this characteristic in short, medium and long petals.

In the characteristic petal width $(\mathrm{PW})$ the highest variation was observed, ANR $(0.90 \mathrm{~cm})$ and ANÃ $(0.64 \mathrm{~cm})$ and PIN $(0.65 \mathrm{~cm})$. The intermediate values were observed between CAA $(0.70 \mathrm{~cm}), \operatorname{MAC}(0.73 \mathrm{~cm})$; BER $(0.77$ $\mathrm{cm})$; and MAQ $(0.83 \mathrm{~cm})$ forming five classes. By the occurrence of the high variation, it was necessary to form a new arrangement, classified in narrow, medium and wide petals.

In the characteristic bracts length (LB) the observed variation occurred in the ANÃ (7.33 mm), PIN (7.23 mm), ANR $(7.08 \mathrm{~mm})$, MAC $(6.98 \mathrm{~mm})$, BER $(6.97 \mathrm{~mm})$; and CAA $(6.12 \mathrm{~mm})$, and the intermediate in the MAQ access $(6.57 \mathrm{~mm})$, forming three classes. Short, medium and long bracts were the suggested classification for this descriptor. As for the characteristic width of the bracts (WB), three classes were formed. The variation occurred between CAA $(2.05 \mathrm{~mm})$ and MAQ $(1.93 \mathrm{~mm})$; and PIN $(1.35 \mathrm{~mm})$, MAC $(1.39 \mathrm{~mm})$, ANÃ $(1.43 \mathrm{~mm})$ and BER $(1.48 \mathrm{~mm})$; the intermediary was the ANR access $(1.78 \mathrm{~mm})$. The classification was described in narrow, medium and wide bracts.

The length and width of the bracts stood out as to the morphological variation within the collection. The accessions that evidenced this characteristic were, ANÃ, BER, MAC and PIN, with long and narrow bracts and the accessions CAA and MAQ, with short and wide bracts. This characteristic was introduced in the characterization process because it is of easy observation when the flowers are closed.

For fruit diameter (FD) the variation between the PIN $(7.89 \mathrm{~mm})$ and BER $(7.44 \mathrm{~mm})$, ANR $(7.45 \mathrm{~mm})$ and ANÃ $(7.53 \mathrm{~mm})$ accessions was verified; and the intermediates in the MAQ $(7.74 \mathrm{~mm})$, MAC $(7.70 \mathrm{~mm})$, CAA $(7.65 \mathrm{~mm})$ accessions. Through observation it was possible to classify this character in small, medium and large fruits.

In relation to this characteristic, larger diameters were found in the PIN access, this data is similar to that described by Kissmann and Groth (2000), where it reports that the mallow plant presents globally shaped fruits and with eight to nine millimeters in diameter, framing in the classification of large fruits. This is one of the characteristics related to the production, so in breeding programs of the species, is sought for plants with larger fruits that will facilitate the harvest and the beneficiation process. 
Peak length (LP1) assessments in the genotypes showed that there is great variability for the character, which varies between MAC $(4.92 \mathrm{~mm})$ and CAA $(3.25 \mathrm{~mm})$. The PIN $(3.85 \mathrm{~mm})$, ANR $(3.49 \mathrm{~mm})$, CAA $(3.25 \mathrm{~mm})$ accessions showed short peduncle characteristics, BER $(4.30 \mathrm{~mm})$ and MAQ $(4.18 \mathrm{~mm})$ and MAC $(4.92 \mathrm{~mm})$ and ANÃ $(4.75 \mathrm{~mm})$ were classified as long. This character is directly related to the size of the fruit and its persistence. Therefore, the PIN access presented good characteristics with large fruits and short peduncles providing their introduction in an improvement program.

Costa, Bentes, Lopes, Álves, and Viana Júnior (2015), make references to studies with peppers in which the characteristic persistence of fruit in peduncle or pedicel is very important in production. Fruits that are not persistent when ripe are more easily detached and easier to harvest but are also easily knocked down by heavy rains and wind causing production losses. The genetic improvement for cultivars with good characteristics should seek fruits that have peduncles from small to intermediates that are not easily knocked over, but which are easily detached at harvest time (Fonseca, R. Lopes, Barros, M. Lopes, \& Ferreira, 2008).

The evaluation of seed length (LS) and seed width characteristics showed little variability, with variation between MAC (4.40 mm) and PIN $(4.27 \mathrm{~mm})$; and BER $(3.59 \mathrm{~mm})$, ANR $(3.68 \mathrm{~mm})$ CAA (3.70 mm) ANÃ $(3.73 \mathrm{~mm})$ and MAQ $(3.78 \mathrm{~mm})$. Due to the low variability observed, a new arrangement was proposed with the classification of short, medium and long seeds (Table 1). This was observed in the characteristic seed width (LS), where variation occurred between MAQ $(3.02 \mathrm{~mm})$, MAC $(2.85 \mathrm{~mm})$ and PIN $(2.63 \mathrm{~mm})$; and BER $(2.20 \mathrm{~mm})$, ANÃ $(2.31 \mathrm{~mm})$ and ANR $(2.38 \mathrm{~mm})$. Due to the importance of these descriptors for the agronomic distinction of the accessions, a new arrangement was proposed, with the seeds classified as narrow, medium and wide (Table 1).

The accessions that present good characteristics for future crosses are MAQ, MAC, PIN, being these seeds classified in medium and long lengths, and medium and wide widths. The values of length and width of seeds found in this research corroborate the classification made by Kissmann and Groth (2000), where it describes the malve seeds with 4.2 to $4.3 \mathrm{~mm}$ in length by 2.6 to $2.8 \mathrm{~mm}$ of width. The mallow is a species that propagates vegetatively and by seeds, however, assessing the physical characteristics of these seeds is not only important for propagation, but also for the sizing and regulation of the machines for the beneficiation process.

The evaluated accessions were not characterized as to the production of seeds due to adverse events in the field. Regarding the utilization of the agronomic characteristics evaluated, they showed a considerable variability among the accessions studied. Leaves, flowers and fruits, presented marked and differentiable characteristics and are commonly used for the distinction of varieties. In this way, the use of these descriptors is valid for the characterization of the species, allowing the possibility of introducing new descriptors in future works. Chart 1 shows the proposed descriptors for the characterization of the mallow. 
Chart 1. Proposed descriptor for characterization of the mallow plant

\begin{tabular}{|c|c|c|c|}
\hline Characteristic & Description of characteristics & Ranges & Code \\
\hline \multicolumn{4}{|l|}{ PLANT } \\
\hline & Low & $\leq 2.27 \mathrm{~m}$ & 1 \\
\hline \multirow[t]{2}{*}{ 1. $\mathrm{PH}$} & Medium & $2.28-3.14 \mathrm{~m}$ & 2 \\
\hline & High & $\geq 3.15 \mathrm{~m}$ & 3 \\
\hline & Smallest & $\leq 7.51 \mathrm{~cm}$ & 1 \\
\hline \multirow[t]{2}{*}{ 2. SD } & Medium & $7.52-8.15 \mathrm{~cm}$ & 2 \\
\hline & Bigger & $\geq 8.16 \mathrm{~cm}$ & 3 \\
\hline \multicolumn{4}{|l|}{$L E A F$} \\
\hline \multirow{3}{*}{ 3. LLE } & Short & $\leq 8.89 \mathrm{~cm}$ & 1 \\
\hline & Medium & $8.90-11.02 \mathrm{~cm}$ & 2 \\
\hline & Long & $\geq 11.03 \mathrm{~cm}$ & 3 \\
\hline \multirow{3}{*}{ 4. WL } & Narrow & $\leq 7.67 \mathrm{~cm}$ & 1 \\
\hline & Medium & $7.68-9.92 \mathrm{~cm}$ & 2 \\
\hline & Wide & $\geq 9.93 \mathrm{~cm}$ & 3 \\
\hline \multirow{3}{*}{ 5. LP1 } & Short & $\leq 6.97 \mathrm{~cm}$ & 1 \\
\hline & Medium & $6.98-10.44 \mathrm{~cm}$ & 2 \\
\hline & Long & $\geq 10.45 \mathrm{~cm}$ & 3 \\
\hline \multicolumn{4}{|l|}{ FLOWER } \\
\hline \multirow{3}{*}{ 6. LP2 } & Short & $\leq 1.59 \mathrm{~cm}$ & 1 \\
\hline & Medium & $1.60-1.71 \mathrm{~cm}$ & 2 \\
\hline & Long & $\geq 1.72 \mathrm{~cm}$ & 3 \\
\hline & Narrow & $\leq 0.76 \mathrm{~cm}$ & 1 \\
\hline \multirow[t]{2}{*}{ 7. WP } & Medium & $0.77-0.89 \mathrm{~cm}$ & 2 \\
\hline & Wide & $\geq 0.90 \mathrm{~cm}$ & 3 \\
\hline \multirow{3}{*}{ 8. LB } & Short & $\leq 6.12 \mathrm{~mm}$ & 1 \\
\hline & Medium & $6.13-6.57 \mathrm{~mm}$ & 2 \\
\hline & Long & $\geq 6.58 \mathrm{~mm}$ & 3 \\
\hline \multirow{3}{*}{ 9. WB } & Narrow & $\leq 1.48 \mathrm{~mm}$ & 1 \\
\hline & Medium & $1.49-1.78 \mathrm{~mm}$ & 2 \\
\hline & Wide & $\geq 1.79 \mathrm{~mm}$ & 3 \\
\hline \multicolumn{4}{|l|}{ FRUIT } \\
\hline \multirow{3}{*}{ 10. FD } & Small & $\leq 7.53 \mathrm{~mm}$ & 1 \\
\hline & Medium & $7.54-7.74 \mathrm{~mm}$ & 2 \\
\hline & Big & $\geq 7.75 \mathrm{~mm}$ & 3 \\
\hline \multirow{3}{*}{ 11. LPE } & Short & $\leq 3.85 \mathrm{~mm}$ & 1 \\
\hline & Medium & $3.86-4.30 \mathrm{~mm}$ & 2 \\
\hline & Long & $\geq 4.31 \mathrm{~mm}$ & 3 \\
\hline \multicolumn{4}{|l|}{ SEED } \\
\hline \multirow{3}{*}{ 13. LS } & Short & $\leq 3.78 \mathrm{~mm}$ & 1 \\
\hline & Medium & $3.79-4.26 \mathrm{~mm}$ & 2 \\
\hline & Long & $\geq 4.27 \mathrm{~mm}$ & 3 \\
\hline \multirow{3}{*}{ 14. WS } & Narrow & $\geq 2.39 \mathrm{~mm}$ & 1 \\
\hline & Medium & $2.40-2.62 \mathrm{~mm}$ & 2 \\
\hline & Wide & $\geq 2.63 \mathrm{~mm}$ & 3 \\
\hline
\end{tabular}

Note. PH: plant height, SD: stem diameter, CL: crown length, LLE: leaf length, WL: leaf width, LP1: length of the petiole, LP2: length of the petal, WP: width of the petal, LB: length of the bracts, WB: width of the bract, FD: fruit diameter, LPE: length of the peduncle, LS: length of the seed, WS: width of the seed.

\subsection{Genetic Parameters of the Descriptors}

In relation to the estimated genetic parameters, the presence of genetic variation coefficient (GVC) values higher than $10 \%$ was verified for most of the characteristics evaluated, especially the characteristic petiole length (LW) with a value equal to $24.74 \%$ (Table 4 ). 
Table 4. Genetic parameters estimated in the variables PH: plant height (m), SD: stem diameter (cm), CL: crown length $(\mathrm{m})$, LLE: leaf length $(\mathrm{cm})$, WL: leaf width $(\mathrm{cm})$, LP1: length of the petiole $(\mathrm{cm})$, LP2: length of the petal $(\mathrm{cm})$, WP: width of the petal $(\mathrm{cm})$, LB: length of the bracts $(\mathrm{mm})$. WB: width of the bract $(\mathrm{mm})$, FD: fruit diameter $(\mathrm{mm})$, LPE: length of the peduncle $(\mathrm{mm}), \mathrm{LS}$ : length of the seed $(\mathrm{mm})$, WS: width of the seed $(\mathrm{mm})$ of seven mallow accessions

\begin{tabular}{lllll}
\hline Parameters & \multicolumn{3}{l}{} \\
\hline Characteristics & Means & CGV(\%) & CGV/CEV & $\operatorname{Inh}^{2}(\%)$ \\
\hline PH & 2.48 & 15.39 & 1.43 & 89.14 \\
SD & 7.50 & 7.62 & 1.26 & 86.36 \\
CL & 3.82 & - & - & - \\
LLE & 9.23 & 12.03 & 1.53 & 90.38 \\
WL & 8.71 & 20.15 & 1.96 & 93.91 \\
LP1 & 7.89 & 24.74 & 1.32 & 87.47 \\
LP2 & 1.65 & 4.70 & 2.34 & 95.64 \\
WP & 0.74 & 12.76 & 4.38 & 98.71 \\
LB & 6.90 & 5.78 & 1.51 & 90.14 \\
WB & 1.63 & 3.38 & 1.21 & 97.63 \\
FD & 7.63 & 14.40 & 1.65 & 91.93 \\
LPE & 4.10 & 8.10 & 2.89 & 91.62 \\
LS & 3.88 & 10.34 & 0.86 & 97.10 \\
WS & 2.54 & CGV & 74.95 \\
\hline
\end{tabular}

Note. CGV\%: coefficient of genetic variation, CGV/CEV: relationship between the coefficient of genetic variation and the coefficient of variation of the experiment e $\operatorname{Inh}^{2} \%$ : Inheritability

The CGG estimates presented by the fruit diameter (FD), with a value of $2.07 \%$, petal length (CL) with $4.70 \%$, bracts length (LB) with $5.78 \%$, stem diameter (SD ) with $7.62 \%$ and seed length (LS), with values equal to $8.10 \%$, presented moderate estimates. The superiority of genetic variability (CGV) against environmental variability $(\mathrm{CEV})$ indicates that the performance of the parents was determined by their genotypes, as evidenced by the CGV/CEV $>1$ values, as well as by their high heritability coefficients $\left(\mathrm{Inh}^{2}\right)$, which ranged from $74.95 \%$ to $98.71 \%$ (Table 4). The exception was observed for seed width (WS) with a value equal to 0.86 , but without, once, that the value is close to one (1). The GVC and CGV/CEV ratio are parameters used in the quantification of genetic variability when it is desired to determine the potential of a population for breeding purposes. The CGG gives an idea of the proportionality of the gain in relation to the mean, and the CGV/CEV > 1 ratio indicates a favorable condition for selection and a good perspective of genetic gain (Araújo et al., 2014; Carvalho et al., 2017). The heritability expresses the reliability of the phenotypic value as an estimator of the genotypic value, so that the greater the heritability, the greater should be the gain with the selection (Falconer \& Mackay, 1996; Carvalho et al., 2015; Carvalho et al., 2017).

\subsection{Grouping of Quantitative Data}

In order to perform the grouping analysis based on the quantitative traits, a dissimilarity matrix was generated (Table 5) obtained by the Mahalanobis genetic distance, from which the dendrogram was generated by the UPGMA hierarchical method (Figure 1).

Table 5. Matrix of dissimilarity between the accessions of mallow

\begin{tabular}{lllllll}
\hline Accessions & ANR & BER & CAA & MAC & MAQ & PIN \\
\hline ANÃ & 827.22 & 429.61 & 337.28 & 463.37 & 818.61 & 169.95 \\
ANR & & 138.6 & 319.31 & 216.22 & 91.04 & 543.17 \\
BER & & & 153.53 & 115.63 & 173.06 & 343.45 \\
CAA & & & 243.89 & 309.3 & 269.56 \\
MAC & & & & 248.67 & 250.38 \\
MAQ & & & & & & 515.92 \\
\hline
\end{tabular}




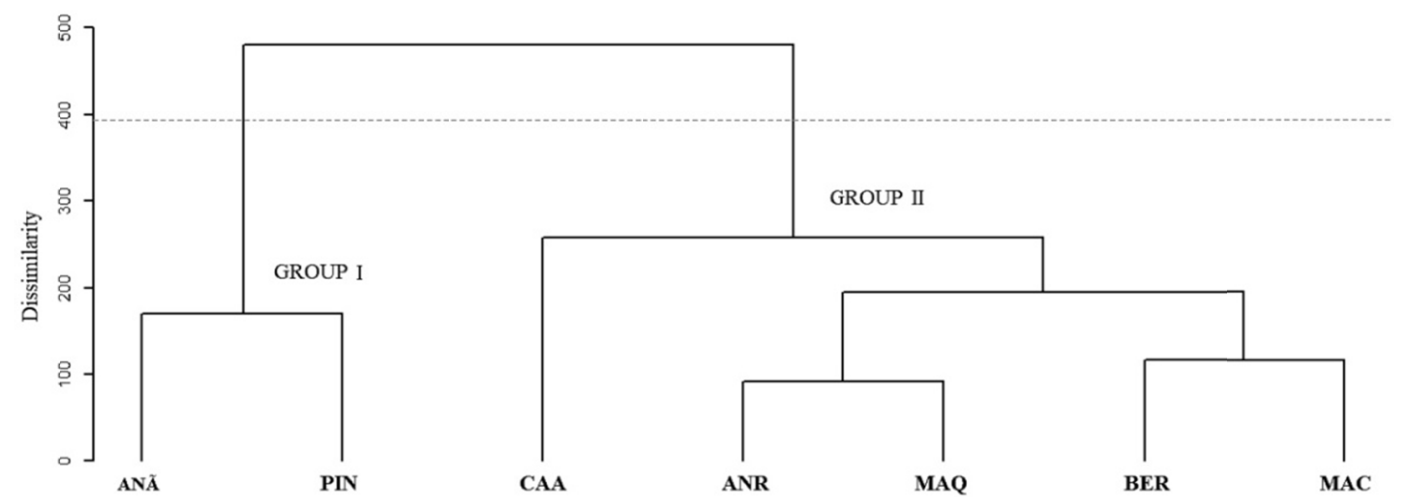

Figure 1. Dendrogram originated by the UPGMA method, based on the dissimilarities of seven mallow accessions, based on 14 quantitative morphological characters using the Mahalanobis method as a measure of dissimilarity. coefficient of correlation: $r=0.72$. The horizontal dashed line represents the cut estimated by the method of Mojema (1977)

The generated dendrogram allowed the formation of two groups. Group I met ANA and PIN accessions, with dissimilarity indexes of 169.95 . This group presented 12 unusual characteristics of the 14 characteristics evaluated. ANÃ, plant characteristics (low stalk, smaller stalk, prostrate growth habit, average cycle of 210 days), leaves (short, narrow petiole and nectar in the central grove), fruits (small and long petiole), seeds (short and narrow). PIN, plant characteristics (medium size, larger stem, erect growth, late cycle greater than 270 days), leaves (long, broad, long petiole, nectary in the central and lateral nerves), fruit (large, short petiole), seeds (long and wide). The divergent characteristics show variability between the accessions.

Group II joined CAA access and the ANR and MAQ, BER and MAC subgroups. The subgroup formed by the accessions ANR and MAQ, with index of 91.04, presented quite dissimilarity with ten divergent characteristics. ANR, leaf-related characteristics (median length, median width and short petiole), flowers (petals of medium length, medium width, long bracts and medium width), fruits (small and short peduncle) and seeds (narrow). MAQ, leaves (short length, narrow width and long petiole), flowers (petals of medium length, medium width, and bracts of long length and medium width), fruit (medium fruit with medium peduncle) e seeds (wide). The second subgroup formed by BER and MAC, and dissimilarity indexes of 115.63 presented 11 divergent characteristics. BER, plant characteristics (mean stature, smaller stem, 210 days average cycle) leaves (average length, average width with 3 lobes), flowers (long e medium), fruits (small and medium peduncle) and seeds (short). MAC, plant characteristics (high, medium stem, late cycle of 280 days) leaves (broad, long petiole with five lobes), flower (short and narrow), fruits (middle and long peduncle) and seeds (long). Regarding CAA access, it is distinguished from other accessions because it presents a characteristic of different flowers (short bracts).

Based on the agronomic characterization, the accesses presented important characteristics for the genetic improvement of the mallow. The ANA and PIN accesses presented 12 divergent characteristics, the ANR and MAQ subgroups, 10 characteristics and BER and MAC, 11 divergent characteristics. These genotypes present attributes of low to medium size plants and mostly erect growth habit, short to medium flowering cycle, medium stem, medium to large fruits, with small to medium sized peduncles.

Considering the place of collection of these accesses, it is evident that the distance between the municipalities and the geographical location, between the Solimões and Amazon rivers, directly influenced the genetic constitution of these materials. Therefore, it is suggested the crosses between the accesses of the first group ANÃ and PIN, with the accessions of the second group BER, MAC and MAQ. The suggested accesses present quite promising characteristics for the implementation of a program of genetic improvement of the species, aiming at superior individuals, for the production of seeds in the western Amazon region.

In an improvement program, the use of parents with high genetic divergence is recommended to maintain the occurrence of higher individuals in subsequent generations. Therefore, cross-breeding between divergent genotypes with desirable agronomic characteristics should be performed (Cruz, Ferreira, \& Pessoni, 2011).

The coefficient of correlation coefficient $(r=0.72)$ presented a good fit for the quantitative variables between the distance chart and its original matrix, showing consistency of the grouping. By Singh's method (Singh, 1981) (Table 6), WP (42\%), followed by LP2 (15\%) and WB (10\%) contributed the most to the genetic divergence. 
Table 6. Relative contribution of 14 quantitative characters for mallow genetic divergence, using Singh's method (Singh, 1981)

\begin{tabular}{lc}
\hline Traits & Relative Contribution (\%) \\
\hline Plant height (PH) & 6.48 \\
Stem diameters (SD) & 1.44 \\
Crown length (CL) & 1.23 \\
Leaf length (LLE) & 1.84 \\
Leaf Width (WL) & 4.68 \\
Length of petiole (LP1) & 1.82 \\
Length of petal (LP2) & 15.44 \\
Width of the petal (WP) & 42.35 \\
Length of bracts (LB) & 1.76 \\
Width of the bracts (WB) & 10.55 \\
Fruit diameter (FD) & 4.79 \\
Length of the peduncle (LPE) & 3.20 \\
Length of the seed (LS) & 2.89 \\
Width of the seed (WS) & 1.45 \\
\hline
\end{tabular}

The flowers of mallow are very sensitive to the touch, due to the occurrence of starry trichomes on all surface (abaxial and adaxial) of the petal, making it difficult to handle. A striking feature is the closure of the flower in a short time, when removed from the plant. Although there are difficulties in its management, it was the characteristic that presented the greatest relative contribution (42\%) among the accessions (Table 6), demonstrating a great deal of genetic variability among the genotypes.

\section{Conclusion}

(1) The characterization based on multicategoric descriptors contributed to the differentiation of the seven accessions of mallow studied, being thus proposed 14 agronomic descriptors for the mallow.

(2) Different groups were formed according to the multivariate analysis, with the recommendation of crosses between the accesses ANÃ/MAC, ANÃ/MAQ and PIN/BER. The intrinsic characteristics among the genotypes are quite promising for a selection work.

\section{References}

Albuquerque, J. A. A., Sediyama, T., Silva, A. A., Sediyama, C. S., Alves, J. M. A., \& Assis Neto, F. (2009). Caracterização morfológica e agronômica de clones de mandioca cultivados no Estado de Roraima. Revista Brasileira de Ciências Agrárias, 4(4), 388-394. https://doi.org/10.5039/agraria.v4i4a3

Alves, R. M., Silva, C. R S., Silva, M. S. C., Silva, D. C. S., \& Sebbenn, A. M. (2013). Diversidade genética em coleções amazônicas de germoplasma de cupuaçuzeiro (Theobroma grandiflorum (Willd. ex Spreng.) Schum.). Revista Brasileira Fruticultura, 35(3), 818-828. https://doi.org/10.1590/S0100-29452013000 300019

Alves, R. P. (2014). Diversidade morfológica, agronômica e potencial para produção de etanol em germoplasma de batata-doce (Master's thesis, Federal University of Sergipe, Brazil). Retrieved from https://ri.ufs.br/bitstream/riufs/6577/1/RODRIGO_PEREIRA_ALVES.pdf

Araújo, B. L., Arnhold, E., Oliveira Junior, E. A. de, \& Lima, C. F. de. (2014). Parâmetros genéticos em cultivares de sorgo granífero avaliados em safrinha. Revista Trópica: Ciências Agrárias e Biológicas, 8, 51-59.

Awan, T. H., Chauhan, B. S., \& Cruz, P. C. S. (2014). Influence of environmental factors on the germination of Urena lobata L. and its response to herbicides. PloS one, 9(3), e90305. https://doi.org/10.1371/ journal.pone. 0090305

Barreto, J. F., \& Resende, M. D. V. (2010). Avaliação genotípica de acessos de mandioca no Amazonas e estimativas de parâmetros genético. Revista Ciências Agrarias, 53(2), 131-136. https://doi.org/10.4322/ rca.2011.018 
Bentes, J., Pereira, H., Mendes, A., Castro, A., \& Cunha, A. (2017). Espaçamento para produção de sementes de malva (Urena lobata L.) em terra firme na região de Manaus-AM. Amazonian Journal of Agricultural and Environmental Sciences, 60(2), 141-146. https://doi.org/10.4322/rca.10605

Bovini, M. G. (2010). Malvaceae s. str. na Reserva Rio das Pedras, Mangaratiba, Rio de Janeiro, Brasil. Rodriguésia, 61(2), 289-301. https://doi.org/10.1590/2175-7860201061211

Bovini, M. G. (2015). Urena in Lista de Espécies da Flora do Brasil. Jardim Botânico do Rio de Janeiro. Retrieved from http://floradobrasil.jbrj.gov.br/jabot/floradobrasil/FB9268

Cardona, J. O. (2010). Análisis de diversidad genética de las razas colombianas de maíz a partir de datos Roberts et al., (1957) usando la estratégia WardWLM. Ciência e Agrotecnologia, 2(1), 199-207.

Carvalho, L. P. de, Farias, F. J. C., Rodrigues, J. I. da S. (2015). Selection for increased fiber length in cotton progenies from Acala and non-Acala types. Crop Science, 55, 985-991. https://doi.org/10.2135/ cropsci2014.08.0547

Castro, A. P. (2015). Análise sistêmica da cultura de malva: Um estudo comparativo nas comunidades Nossa Senhora das Graças e Monte Sião no município de Manacapuru (Master's thesis, Federal University of Amazonas, Brazil). Retrieved from https://tede.ufam.edu.br/handle/tede/4890

Cavalho, L. P. de, Rodrigues, J. I. S da, \& Farias, F. J. C. (2017). Seleção de linhagens de algodão para alto teor de óleo. Pesq. Agropec. Bras, 52(7), 11.

Conceição, L. D. H. C., Doerr, L. M. W., \& Barbosa, N. J. F. (2010). Seleção para tolerância ao alumínio em milho com base em parâmetros genéticos e análise multivariada. Bragantina, 69(4), 807-814. https://doi.org/10.1590/S0006-87052010000400005

Costa, L.V., Bentes, J. L. S., Lopes, M. T. G., Alves, S. R. M., \& Viana Júnior, J. M. (2015). Caracterização de acessos de pimentas do Amazonas. Horticultura Brasileira, 33(3), 290-298. https://oi.org/10.1590/ S0102-053620150000300003

Cruz, C. D. (2013). Genes: A software package for analysis in experimental statistics and quantitative genetics. Acta Scientiarum. Agronomy, 35(3), 271-276. https://doi.org/10.4025/actasciagron.v35i3.21251

Cruz, C. D., Carneiro, P. C. S., \& Regazzi, A. J. (2014). Modelos biométricos aplicados ao melhoramento genético (3rd ed., Vol. 2, p. 668). Viçosa: UFV.

Cruz, C. D., Ferreira, F. M., \& Pessoni, L. A. (2011). Biometria aplicada ao estudo da diversidade genética. Visconde do Rio Branco: Suprema.

Fagbohun, E. D., Asare, R. R., \& Egbebi, A. O. (2012). Chemical composition and antimicrobial activities of Urena lobata L. (Malvaceae). Journal of Medicinal Plants Research, 6(12), 2256-2260. https://doi.org/ 10.5897/JMPR10.233

Fajardo, J. D. V. (2016). Caracterização morfoagronômica de progênies de Guaranazeiro (42f., Dissertação, Mestrado em Agronomia Tropical, Universidade Federal do Amazonas, Brasil).

Falconer, D. S., \& Mackay, T. F. C. (1996). Introduction to quantitative genetics (4th ed., p. 464). New York: Longman.

Faleiro, F. G., Junqueira, N. T. V., Braga, M. F., \& Peixoto, J. R. (2011). Pré-melhoramento do maracujá. In M. A. Lopes, A. P. Favero, M. A. J. Ferreira, F. G. Faleiro, \& S. M. Folle (Eds.), Pré-melhoramento de plantas: estado da arte e experiências de sucesso (pp. 550-569). Brasília: Embrapa Informação Tecnológica.

Fonseca, R. M., Lopes, R., Barros, W. S., Lopes, M. T. G., \& Ferreira, F. M. (2008). Morphologic characterization and genetic diversity of Capsicum chinense accessions along the upper Rio Negro-Amazonas. Crop Breeding and Applied Biotechnology, 8, 187-194. https://doi.org/10.12702/ 1984-7033.v08n03a02

Franco, J., Crossa, J., Taba, S., \& Shands, H. (2005). A sampling strategy for conserving genetic diversity when forming core subsets. Crop Science, 45(3), 1035-1044. https://doi.org/10.2135/cropsci2004.0292

Gepts, P. (2006). Plant genetic resources conservation and utilization: The accomplishments and future of a societal insurance policy. Crop Science, 46(5), 2278-2296.

Islam, M. T., Ibrahim, M., Ahsan, M. Q., Chowdhury, M. M. U., Hossain, M. A., \& Rashid, M. A. (2012). Phytochemical and pharmacological investigations of Uraria lagopodies DC. and Urena lobata L. Dhaka University Journal of Pharmaceutical Sciences, 11(1), 65-69. https://doi.org/10.3329/dujps.v11i1.12490 
Joly, A. B. (2002). Botânica-introdução à taxonomia vegetal (13th ed., p. 808). São Paulo: Ed. IBEP.

Kissmann, K. G., \& Groth, D. (2000). Plantas infestantes e nocivas (2nd ed., p. 726). São Paulo: BASF, Tomo III.

Krishnamurthy, S. L., Reddy, K. M., \& Rao, A. M. (2013). Genetic variation, path and correlation analysis in crosses among Indian and Taiwan parents in Chilli. Vegetable Science, 40, 210-213.

Laviola, B. G., Bhering, L. L., Mendonça, S., Rosada, T. B., \& Albrecht, J. C. (2011). Caracterização morfoagronômica do banco de germoplasma de pinhão manso na fase jovem. Bioscience Journal, 27(3), 371-379.

Mojema, R. (1997). Hierarchical grouping methods and stopping rules: an evaluation. The Computer Journal, 20 , 359-363. https://doi.org/10.1093/comjnl/20.4.359

Nahar, K., Deb, A. C., Samad, M. A., \& Khaleque, M. A. (2010). Genetic study of some agronomical traits through single cross analysis in blackgram (Vigna mungo (L.) Hepper). International Journal of Sustainable Crop Production, 5(3), 22-28.

Noda, S. N. (2010). Agricultura familiar amazonense: Mobilidade e relações de trabalho na produção de juta e malva. In W. A. Carlos, F. Da S. Aldenor, H. A. K. Oyama, \& T. De J. P. Fraxe (Eds.), A cultura de juta e malva na Amazônia Ocidental: sementes de uma nova racionalidade ambiental. São Paulo: Editora Annablume

Purnomo, Y., Soeatmadji, D. W., Sumitro, S. B., \& Widodo, M. A. (2015). Anti-diabetic potential of Urena lobata leaf extract through inhibition of dipeptidyl peptidase IV activity. Asian Pacific Journal of Tropical Biomedicine, 5(8), 645-649. https://doi.org/10.1016/j.apjtb.2015.05.014

Quintal, S. S. R., Viana, A. P. V., Gonçalves, L. S. A., Pereira, M. G., \& Júnior, A. T. A. (2012). Divergência genética entre acessos de mamoeiro por meio de variáveis morfoagronômicas. Semina: Ciências Agrárias, 33(1), 131-142. https://doi.org/10.5433/1679-0359.2012v33n1p131

R-Core Team. (2018). R: A language and denvironment for statistical computing. R-Foundation for Statistical Computing, Vienna, Austria. Retrieved from http://www.Rproject.org/Andgt

Scott, A. J., \& Knott, M. (1974). A cluster analysis method for grouping means in the analysis of variance. Biometrics, 30(2), 507-512. https://doi.org/10.2307/2529204

Singh, D. (1981). The relative importance of characters affecting genetic divergence. The Indian Journal of Genetic and Plant Breeding, 41(1), 237-245.

Sudré, C. P., Gonçalves, L. S. A., Rodrigues, R., Amaral Júnior, A. T., Riva-Souza, E. M., \& Bento, C. S. (2010). Genetic variability in domesticated Capsicum spp as assessed by morphological and agronomic data in mixed statistical analysis. Genetics and Molecular Research, 9(1), 283-294. https://doi.org/10.4238/ vol9-1gmr698

\section{Copyrights}

Copyright for this article is retained by the author(s), with first publication rights granted to the journal.

This is an open-access article distributed under the terms and conditions of the Creative Commons Attribution license (http://creativecommons.org/licenses/by/4.0/). 